TITLE:

\title{
New Approach of Cultural Aesthetic Using Sound and Image
}

AUTHOR(S):

Pang, Yunian; Tosa, Naoko

CITATION:

Pang, Yunian ...[et al]. New Approach of Cultural Aesthetic Using Sound and Image. 2015 International Conference on Culture and Computing (Culture Computing) 2015: 193-194

ISSUE DATE:

2015-10

URL:

http://hdl.handle.net/2433/232628

RIGHT:

(c) 2015 IEEE. Personal use of this material is permitted. Permission from IEEE must be obtained for all other uses, in any current or future media, including reprinting/republishing this material for advertising or promotional purposes, creating new collective works, for resale or redistribution to servers or lists, or reuse of any copyrighted component of this work in other works.; この論文は出版社版でありません。引用の際には出版社版をご確認ご利用ください。;This is not the published version. Please cite only the published version. 


\section{New Approach of Cultural Aesthetic Using Sound and Image}

\author{
Yunian Pang \\ Graduate School of Advanced Integrated Studies in Human \\ Survivability, \\ Kyoto University \\ Kyoto, Japan \\ pang.yunian.87r@st.kyoto-u.ac.jp
}

\author{
Naoko Tosa \\ Center for The Promotion of Excellence in Higher \\ Education, \\ Kyoto University \\ Kyoto, Japan \\ tosa@media.kyoto-u.ac.jp
}

\begin{abstract}
With the help of science and technology, many interesting works of art can be created, including transforming sound into images. If we combine these images with cultural elements, new approaches to preserve existing cultures can be developed. We put some viscous liquid on rubber film which covers a speaker and played various sound. We then see marvelous shapes simulating the sounds that usually cannot be seen with the help of a high speed camera. I studied how the frequency of sound and liquid materials (water, pigment, foam, jelly) influence these shapes. High liquid viscosity reduces the liquid's jump height and maintains a consistent shape; low liquid viscosity enables higher jumps and transformations into small spherical drops. At the frequency of $32 \mathrm{hz}$, liquid jumps are expected to reach the greatest heights. Sine wave sounds can propel liquid further than zigzag waves. I also made some interesting discoveries. If we use this approach to reveal ancient culture, it would be an innovative approach to revive the sounds and images of disappearing ancient cultures.
\end{abstract}

Keywords—sound images; sound frequency; high-speed camera; liquid viscosity

\section{INTRODUCTION}

Science and technology developed exponentially when in the 21 th century. The development provided new approaches for creating art works. With the help of computers, it is possible for us to transform sound into images.

These forms of art making can arouse the curiosity of viewers. This curiosity makes viewers pay closer attention to the art work. Meanwhile, this new way of thinking can be planted in the mind of people who see the art work, and inspire their imagination. If we combine aesthetic elements to new science and technology, we can create an appeal for things that we have never shown to people.

Linden Gledhill combined different colors of water based paints, and used sound as the trigger for the camera to capture intricate shapes [1]

The work made by Naoko Tosa named "Sound of Ikebana" was exhibited to the world, and gained a lot of applause [2][3]. This work succeeded in transforming sound into images with the help of a highspeed camera. The work was integrated with cultural elements, especially with elements of the ancient design of Japan called Rimpa. This influenced the world greatly, and improved global cultural communication.

Gledhill's work and Sound of Ikebana are both works made by the approach of science technology, which change sound into images.

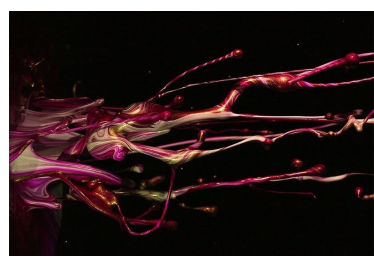

fig. 1. Work by Naoko Tosa.
Feng Chen from Kyoto University also examined how to transform sound into images [3]. However, her paper didn't discuss the influence of sound frequency on sound shapes, so I explore this aspect in this paper.

\section{SYSTEM PRINCIPLES}

To transform sound into images, we use a stretched rubber sheet covering a speaker. We then add paint or other materials on this sheet. A computer is used to control and play the sounds through the speaker. The sound vibration is then felt by the rubber sheet, and the sheet thrusts the material into the air. Various shapes formed by the paint in the air were then captured with our high-speed camera.

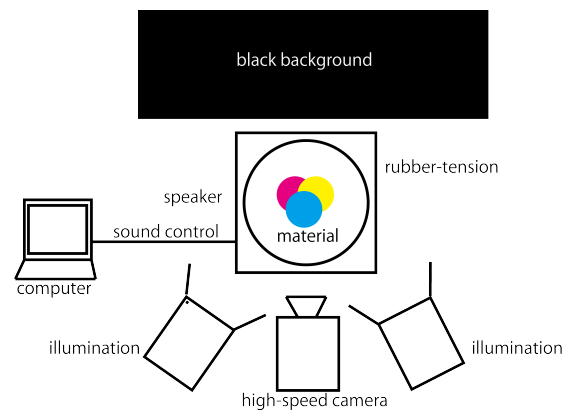

fig. 2. System configuration.

\section{A. Experiment}

III. EXPERIMENT AND RESULTS

Pure Data (PD), a visual programing language which provides interactive computer music and multimedia works, was used.

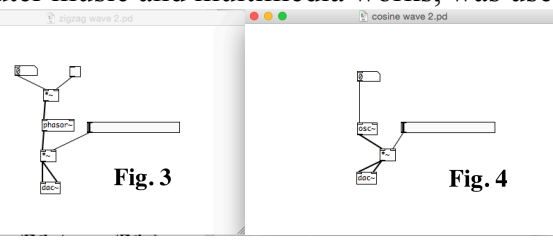

fig. 3. and fig. 4. The PD program for the experiment

I made this visual program to control the types of sound waves. Figure 1 displays a PD program for making zigzags sound wave. Figure 4 shows the program for sine wave sounds. We can use the little box on top to control the frequency, and use the long horizontal bar to control the volume. Among the different shape of sound wave, sine wave can vibrate the materials more than zigzag wave.

\begin{tabular}{|c|c|c|c|}
\hline \multicolumn{4}{|c|}{ Influence of Different Quantity of Paint* } \\
\hline $\begin{array}{c}\text { Amount of } \\
\text { paint }\end{array}$ & $3 \mathrm{ml}$ & $6 \mathrm{ml}$ & $10 \mathrm{ml} \sim$ \\
\hline \multirow[t]{3}{*}{ Phenomena } & $\begin{array}{l}\text { A small and } \\
\text { unclear inverted } \\
\text { triagle fountain } \\
\text { was created on } \\
\text { the center of the } \\
\text { tension. }\end{array}$ & $\begin{array}{l}\text { A clear inverted } \\
\text { triangle fountain } \\
\text { was created on the } \\
\text { center of the } \\
\text { tension. }\end{array}$ & $\begin{array}{l}\text { A big inverted } \\
\text { triagle shape was } \\
\text { generated like a } \\
\text { erupting volcano. }\end{array}$ \\
\hline & & & \\
\hline & & & \\
\hline
\end{tabular}


TABLE II.

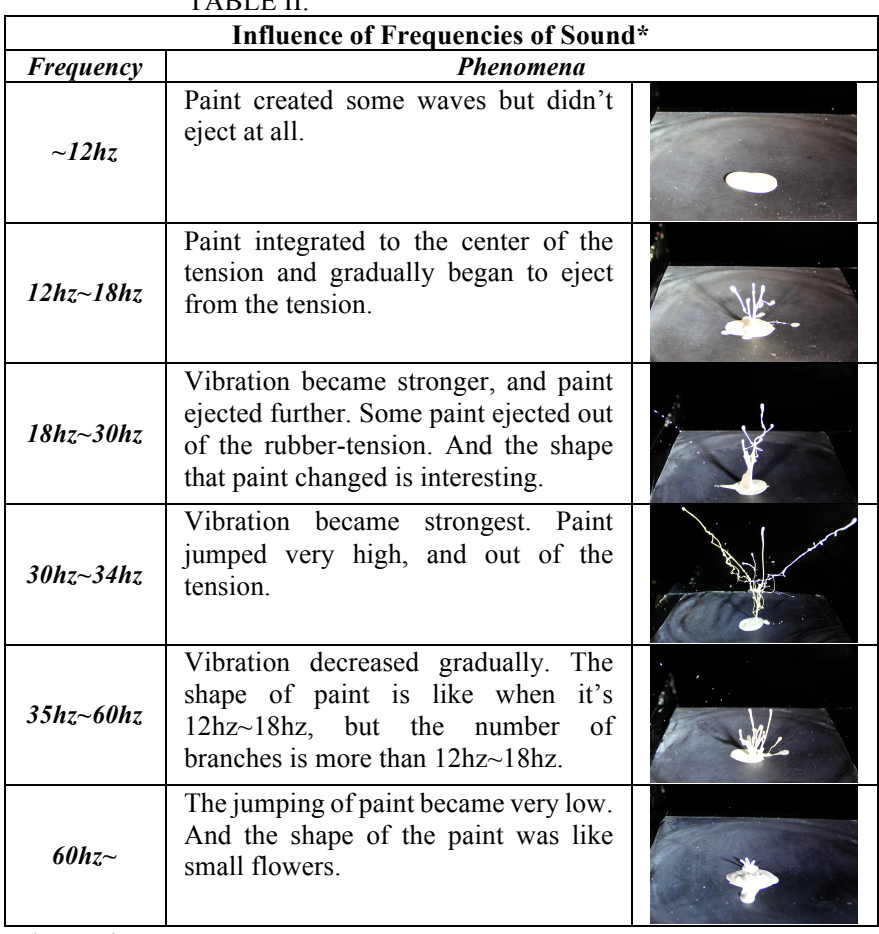

*Other variates were same.

TABLE III.

\begin{tabular}{|c|c|c|}
\hline \multicolumn{3}{|c|}{ Influence of Viscosity in Different Materials* } \\
\hline Material & Phenomena & \\
\hline Water & $\begin{array}{l}\text { Water jumped from the center of the } \\
\text { rubber-tension and then rapidly change } \\
\text { to small sphere shape drops. And it } \\
\text { jumped very far. }\end{array}$ & \\
\hline Paints & $\begin{array}{l}\text { The height that paints jumped is only } \\
\text { half of water's. Andidn't seprated to } \\
\text { small drops and maitained a unbroke } \\
\text { shape. Finally, it change to stream } \\
\text { shape. }\end{array}$ & \\
\hline Foam & $\begin{array}{l}\text { Though the shape of foam changed a } \\
\text { lot, but it didn't be seprated. }\end{array}$ & \\
\hline Jelly & $\begin{array}{l}\text { Jelly only simulated big waves on the } \\
\text { surface, but didn't jump at all. }\end{array}$ & \\
\hline
\end{tabular}

*Other variates were same.

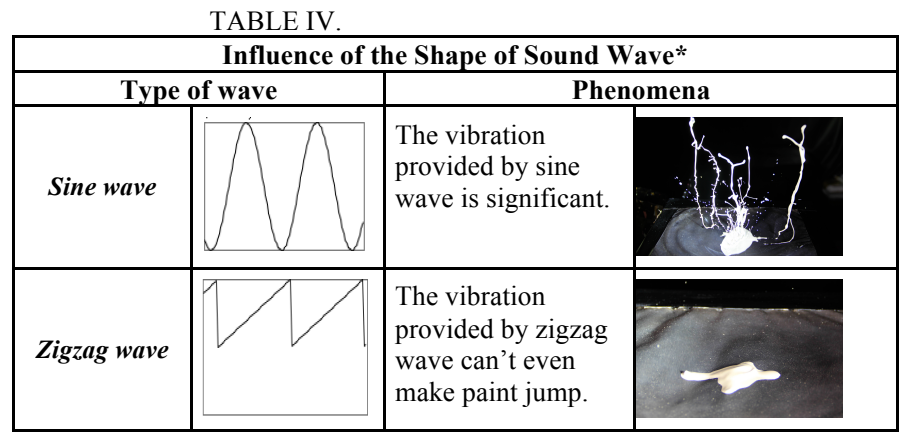

TABLE V.

\begin{tabular}{|c|l|}
\hline \multicolumn{3}{|c|}{ Influence of Viscosity in same material* } \\
\hline $\begin{array}{c}\text { Viscosity } \\
\text { Viscosity }\end{array}$ & $\begin{array}{l}\text { The paint didn't be seperated or jump } \\
\text { up from the tension. But changed its } \\
\text { shape to a small flower. }\end{array}$ \\
\hline $\begin{array}{l}\text { Medium } \\
\text { Viscosity }\end{array}$ & $\begin{array}{l}\text { The paint jumped further than high } \\
\text { viscosity. And the shape was } \\
\text { interesting, which changed into stream } \\
\text { shape. }\end{array}$ \\
\hline $\begin{array}{c}\text { Low } \\
\text { Viscosity }\end{array}$ & $\begin{array}{l}\text { When the paint ejected to air, it } \\
\text { changed to small drops immediatly. } \\
\text { And it jumped furthest. }\end{array}$ \\
\hline *Other variates were same.
\end{tabular}

\section{B. Result and Analysis}

We know from the experiences above that, with a small amount of water, the shape in which water jumps is not clear. When the water quantity is large, the water is propelled further. Sound frequency also influences the vibration and the shapes formed by the liquid. Under $12 \mathrm{hz}$, the water is barely displaced. From $12 \mathrm{hz}$ to $30 \mathrm{hz}$, the vibration of the water is observable. At approximately $32 \mathrm{hz}$, the water vibration is at its strongest, then gradually decreases and disappears disappears at $60 \mathrm{hz}$. When we are operating at a good frequency (especially $32 \mathrm{hz}$ ), the vibrations make the paint jump highest, or jump into various shapes. The viscosity of the materials also influences the shape. The material remains intact when its viscosity value is high, forming various shapes when propelled materials by the speaker. Materials with low viscosity divide when kinetic energy propels them upward such as water. As for foam (a material with low viscosity), since the quality of the material was too low, the material was not able to absorb enough kinetic energy. So foam was not greatly displaced despite its low viscosity.

With high viscosity liquid and high frequency, we can simulate mountains; with low viscosity liquid and low frequency, we can simulate rain. By properly understanding these elements, we can control the shape of sound images.

\section{CONCLUTION}

From the experience above, we discovered that the shape of sound can be controlled to some degree. However, there still are some aspects of sound shaping that are unknown. For example, what phenomena can be created if we use the human voice as the vibration source, or a combination of deferent color materials? So I will continue to conduct research in this field. My home country, China, has a long history and sophisticated culture. In the next step, I am going to try to combine ancient Chinese culture (especially by using the bronze bell, an ancient Chinese music instrument, as the vibration source, and use the cinnabar or lapis lazuli as paint) with this kind of brand-new approach to create an artwork, with the ambition of helping more people understand Chinese culture.

\section{REFERENCES}

[1] Linden Gledhill, "Paint Splash", web site, http://www.lindengledhill.com/paint-splash/ .

[2] Naoko Tosa, “琳派 400 年記念プロジェケクしションマッピング”, http://www.tosa.media.kyoto-u.ac.jp/RIMPA400/index-jp.html

[3] 中谷日出, NHK, web site, “くらし论解説「琳派 400 年の最新映像表現」”, http://www.nhk.or.jp/kaisetsu-blog/700/216896.html, 14, May, 2015.

[4] Feng Chen, Tomoji Sawada, and Naoko Tosa, "Sound Based Scenery Painting", 2013.

[5] Kahn, Douglas, "Noise, Water, Meat: A History of Sound in the Arts", Cambridge: MIT Press, ISBN 0-262-61172-4, 2001. 